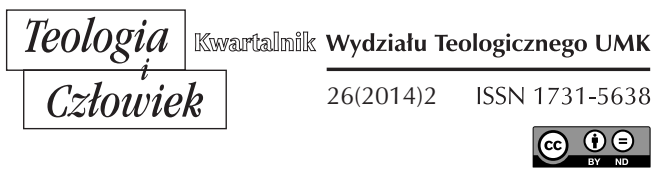

KS. MAREK KLUZ*

\title{
PRZESTRZEGANIE ZASAD MORALNYCH W DZIAŁALNOŚCl POLITYCZNEJ POWINNOŚCIĄ SUMIENIA
}

DOI: http://dx.doi.org/10.12775/TiCz.2014.016

\section{WSTĘP}

Życie obywatela to - przynajmniej z chrześcijańskiego punktu widzenia - droga, która prowadzi do Boga, a na której spotkać można co najmniej dwie niewykluczające się rzeczywistości: polityczną i religijną. Chrześcijanin winien się angażować w życie polityczne, a jednocześnie postępować zgodnie z właściwym systemem moralnym, zachowując w polityce wszystkie zasady proponowane przez Magisterium. Kościół od dawna ustami swoich reprezentantów pojmował działalność polityczną jako rzeczywistość porządku duchowego, realizację wartości moralnych, formę komunikacji międzyosobowej. Zaangażowanie polityczne prowadzi samo w sobie - o ile jest autentyczne - do realizacji wartości moralnych poprzez poszukiwanie prawdy, sprawiedliwości i miłości. Zdając sobie

* Ks. dr hab. Marek Kluz - adiunkt z habilitacją przy Katedrze Teologii Moralnej i Duchowości Wydziału Teologicznego Sekcja w Tarnowie Uniwersytetu Papieskiego Jana Pawła II w Krakowie. Autor kilku książek i ponad 70 artykułów naukowych poświęconych moralności małżeńsko-rodzinnej, wychowania moralnego, bioetyce, moralności życia społecznego i działalności socjalno-charytatywnej 
sprawę z możliwych zagrożeń w tej dziedzinie, trzeba mówić o potrzebie formacji w duchu katolickim, dla wszystkich chrześcijan pełniej uczestniczących w życiu politycznym. Formacja ta jest konieczna, aby przenikać świat polityki duchem chrześcijańskim.

\section{PERSONALISTYCZNY WYMIAR POLITYKI}

Integralna koncepcja człowieka zwraca uwagę na potrzebę i konieczność życia społecznego. Społeczny charakter ludzkiej natury sprawia, że każdy człowiek - właśnie w życiu społecznym - odnajduje możliwość szybszego i pełnego zrealizowania swego osobistego rozwoju. Jest to możliwe dzięki dobru, jakie zawiera w sobie życie społeczne. Dobro wspólne nie tylko ogniskuje wokół siebie określoną grupę ludzi, ale jest także dla każdego członka owej grupy dobrem osobowym ${ }^{1}$. Skoro więc dobro wspólne przyczynia się do istnienia grupy i osobowego rozwoju członków tej grupy, istnieje uzasadniona konieczność zorganizowanej troski o pielęgnowanie tego właśnie dobra. Służba na rzecz dobra wspólnego to najgłębszy sens polityki, dokonującej się $\mathrm{w}$ ramach różnych grup społecznych².

Tak rozumiana polityka oznacza zarówno wszelką pozytywną działalność na rzecz uzyskania, utrzymania i zdobycia władzy, jak i sztukę rządzenia państwem. O ile polityka jest zorientowana na dobro wspólne, o tyle także stawia za swój cel człowieka, rozwijającego się dzięki uczestnictwu w dobru wspólnym. To dobro leży u podstaw rozumienia władzy. Dobro wspólne, według nauczania soborowego „obejmuje sumę tych warunków życia społecznego, dzięki którym jednostki, rodziny i zrzeszenia mogą pełniej i łatwiej osiągnąć swoją własną doskonałość"3. W katolickiej koncepcji dobro wspólne jest zbiorową wartością społeczeństwa obywatelskiego obejmującą doskonałość osób i ich zrzeszeń. Instytucje państwowe i samorządowe są zaś tylko urządzeniami instrumentalnymi dobra wspólnego ${ }^{4}$.

${ }^{1}$ Por. J. Gałkowski, Królestwo Boże na ziemi, „Więź” 25 (1982), nr 8, s. 94.

${ }^{2}$ W encyklice Jana Pawła II Laborem exercens polityka określana jest ,jako roztropna troska o dobro wspólne". Tenże, Encyklika "Laborem exercens", Wrocław 1995, nr 20.

${ }^{3}$ KDK 74.

${ }^{4}$ Por. J. Wojciechowski, O wspólne dobro, „Magazyn - Słowo Dziennik Katolicki” 28 (1994), s. 12. 
Z uwagi na dobro wspólne jednostka lub grupa ludzi posiada uprawnienia do nakładania na podwładnych zobowiązań, by w ramach życia społecznego urzeczywistniali dobro wspólne. Ale należy pamiętać, że tylko władza, która została swobodnie i uczciwie wybrana przez członków życia społecznego, może w pełni egzekwować zobowiązania nakładane na tych członków. Tylko władza prawowierna ma prawo spełniać swoją społeczną misję, ponieważ według nauki społecznej Kościoła tylko ona jest uczestnictwem we władzy pochodzącej od Boga ${ }^{5}$. Wobec władzy prawowiernej członkowie życia społecznego winni zachować posłuszeństwo ${ }^{6}$. W społeczeństwach demokratycznych działalność takiej władzy podlega też społecznej kontroli. Jest to kontrola o charakterze prawnym lub publicznym.

To wszystko daje do zrozumienia, że cała polityka ma rację bytu tylko wówczas, gdy służy człowiekowi, gdy człowiek jest celem życia politycznego. Z uznania tej prawdy, że człowiek jest celem działalności politycznej, wynika zatem zobowiązanie do budowania takiego ustroju politycznego, który pozwoli zachować uczestnictwo, wolność i odpowiedzialność poszczególnych jednostek, podmiotów życia politycznego ${ }^{7}$. W tym sensie katolicka nauka społeczna opowiada się za demokracją i pomocniczą koncepcją państwa ${ }^{8}$.

Główną ideą systemu demokratycznego jest zasada uczestnictwa obywateli w sprawowaniu władzy, czyli idea partycypacji politycznej ludności ${ }^{9}$. Polega ona na „rządach ludu”, czyli obywateli, sprawowanych w formie głosowań jednomyślnych lub większością głosów w podejmowaniu decyzji $\mathrm{w}$ ważnych sprawach państwa. Istotą demokratycznego sprawowania władzy jest także równość praw osób posiadających status obywateli, uczestniczących w bezpośrednim lub pośrednim decydowaniu o sprawach państwa. Pojęciem „demokracja” określa się więc taki ustrój państwa i system wykonywania władzy państwowej, w którym ogół

${ }^{5}$ Por. tamże.

${ }^{6}$ Por. J. Majka, Społeczne wymiary grzechu, "Colloquium Salutis” 10 (1978), s. 42.

7 Por. P. Jarecki, Polityka w świetle nauki społecznej Kościoła, "Collectanea Theologica" 60 (1990) nr 4, s. 86-87.

8 Por. Jan Paweł II, Encyklika „Redemptor hominis”, Warszawa 1979, nr 17; Por. także: J. Kondziela, Moralne podstawy demokratycznego ładu społecznego w świetle katolickiej nauki społecznej, „Ethos” 5 (1992), nr 18-19, s. 155; W. Piwowarski, Państwo pomocnicze w katolickiej nauce społecznej, "Chrześcijanin w Świecie” 23 (1993), nr 2, s. 169.

9 Por. J. Krucina, Społeczność - kontrakt czy uczestnictwo, "Colloquium Salutis" 25 (1993), s. 117; W. Weber, Person Gesellschaft, München, Padeborn, Wien 1978, s. 222. 
członków społeczeństwa będących obywatelami uczestniczy w decydowaniu o sprawach państwa ${ }^{10}$.

Trzeba przyznać, że nauka społeczna Kościoła już od dawna głosi swoje przychylne nastawienie do demokracji, jako sposobu rządzenia państwem, co pozwala jej uważać się za jednego z jej promotorów. Niemniej jednak aprobata ta nie jest pozbawiona pewnych warunków, które demokracja musi spełniać, aby uchodzić za ustrój godny człowieka. Ogólnie rzecz biorąc, odnoszą się one, po pierwsze, do respektowania pierwszeństwa prawa naturalnego przed jakimikolwiek regulacjami prawnymi, a przede wszystkim tymi wyłonionymi za pomocą demokratycznych procedur, po drugie, do uznania integralnej koncepcji osoby ludzkiej uwzględniającej także jego transcendentne implikacje. Szczególnie wyraźnie ten styl myślenia widoczny jest w encyklice społecznej Jana Pawła II Centesimus annus, ogłoszonej 1 maja $1991 \mathrm{r}$. w setną rocznicę ukazania się encykliki Leona XIII Rerum novarum. Doceniając demokrację jako system, „,który zapewnia udział obywateli w decyzjach politycznych i rządzonym gwarantuje możliwość wyboru oraz kontrolowania własnych rządów", Jan Paweł II przestrzega przed jej wykrzywieniem w stronę dyktatury „wąskich grup kierowniczych, które dla własnych korzyści albo celów ideologicznych przywłaszczają sobie władzę w państwie"11. Określając warunki prawidłowego rozwoju systemu demokratycznego, papież podkreśla w encyklice, że „autentyczna demokracja możliwa jest tylko w państwie prawa i w oparciu o poprawną koncepcję osoby ludzkiej"12, a więc musi być to demokracja odniesiona do określonych wartości, stojących na straży pełnej prawdy o człowieku. „Demokracja bez wartości - jak zauważa Jan Papież II - łatwo sie przemienia $w$ jawny lub zakamuflowany totalitaryzm"13. To wskazuje pośrednio na to, że działalność polityczna na rzecz tworzenia struktur demokratycznych zarówno w skali państwa, jak i w skali międzynarodowej będzie zawsze narażona na istotne zniekształcenie, jeśli nie będzie oparta na fundamentalnej prawdzie o człowieku i na systemie wartości.

${ }^{10}$ Por. Jan Paweł II, Demokracja i wartości. Przestanie do uczestników VI Sesji Plenarnej Papieskiej Akademii Nauk Społecznych (Watykan - 23 lutego 2000), „L'Osservatore Romano" (wyd. pol.) 21 (2000), nr 6, s. 4. Por. także: W. Piwowarski, Demokracja, „Ateneum Kapłańskie” 76 (1971), t. 63, s. 18.

${ }^{11}$ Jan Paweł II, Encyklika "Centesimus annus", Wrocław 1991, nr 46.

12 Tamże.

${ }^{13}$ Tamże. Por. także: G. Weigel, Centesimus annus a przyszłość demokracji: powtórna lektura, tłum. M. Ritter, J. Merecki, w: Jan Paweł II, Centesimus annus. Tekst i komentarze, red. F. Kampka, C. Ritter, Lublin 1998, s. 115-131. 
Tak więc, aby demokracja nie przekształciła się w kolejny totalitaryzm $^{14}$, musi być oparta na wartościach etycznych, które bardziej niż jakiekolwiek procedury włączające obywatela we współdecydowanie o państwie gwarantują jego podmiotowość w wymiarze politycznym, społecznym i gospodarczym. Jakość demokracji w ostatecznym rozrachunku zależy od tworzących ją ludzi, od ich obywatelskiego zaangażowania, od wartości, którym służą i które kształtują ich osobowość, od wrażliwości ich sumień, a także od świadomości swojej roli we współdecydowaniu o losie wspólnoty, w której żyją.

Niebezpieczną pułapką jest pojmowanie demokracji wyłącznie przez pryzmat procedur w niej obowiązujących. Plebiscyty, wybory czy referenda nie mogą rozstrzygać o istnieniu bądź nie wartości dla człowieka najważniejszych, jak choćby początku i końcu jego życia. Podobnie nie można orzekać o jakości życia i na tej podstawie przyznawać bądź odbierać przysługujące z natury każdemu człowiekowi prawa. Chodzi zatem o zagwarantowanie $\mathrm{w}$ demokracji takiego zespołu wartości podstawowych - trwałych i nienaruszalnych, które zarówno dla jednostki, jak i dla tworzonych przez nią społeczności będą punktem wyjścia w tworzeniu najdogodniejszego systemu sprawowania władzy, a także, gdy zajdzie taka potrzeba, będą pewnym źródłem sprawiedliwego osądu. Taki ustrój, który by nie szanował i nie popierał ludzkich spraw, osobistych i społecznych, ekonomicznych i politycznych, nie byłby godny człowieka ${ }^{15}$.

Demokracja wymaga mocnych fundamentów w postaci uznania i poszanowania wszystkich ludzkich praw. Wśród zasadniczych praw należy wymienić prawo człowieka do życia od chwili poczęcia; prawo do życia w zjednoczonej wewnętrznie rodzinie i środowisku moralnym sprzyjającym rozwojowi osobowości; prawo do rozwijania własnej inteligencji i wolności w poszukiwaniu prawdy; prawo do uczestniczenia w pracy dla doskonalenia dóbr ziemi i zdobycia środków utrzymania dla siebie i swych bliskich; prawo do swobodnego założenia rodziny oraz

14 Termin „totalitaryzm” powstał na łacińskim słowie tutus oznaczającym „wszystko", „całość". Po raz pierwszy pojęcia "totalitaryzm” na oznaczenie charakteru państwa użyto w czasach Mussoliniego. Od tego czasu nazwą tą określa się system władzy państwowej opartej na nieograniczonych kompetencjach władzy cywilnej. Staje się więc jasne, że totalitaryzm to system, który rości sobie pretensje do całkowitego władania, kontroli nad wszystkimi sferami życia społecznego i każdej jednostki. Por. P. Wróbel, Demokracja jako ustój władzy państwa w encyklikach Jana Pawła II, Wrocław 2010, s. 97.

15 Por. Jan Paweł II, Encyklika "Sollicitudo rei socialis", Wrocław 1987, nr 33. 
przyjęcia i wychowania dzieci, dzięki odpowiedzialnemu realizowaniu własnej płciowości.

Do funkcji demokratycznego państwa należy zapewnienie możliwości swobodnego działania i podejmowania inicjatyw, reformowanie niesprawiedliwych struktur i usuwanie z życia negatywnych zjawisk, które zagrażają człowiekowi. Do zadań państwa należy też popieranie działalności przedsiębiorstw poprzez tworzenie warunków zapewniających możliwości pracy. Państwo powinno stwarzać takie możliwości zatrudnienia (prawo pracy), aby nie uwłaczały godności człowieka, oraz rozwijać aktywną politykę pracy $\mathrm{w}$ różnych sektorach produkcji (polityka pełnego zatrudnienia) ${ }^{16}$. Z polityką gospodarczą wiąże się sprawa troski o wszystkich obywateli, przede wszystkim zaś o ubogich. Zdaniem papieża Benedykta XVI w wielu przypadkach „ubodzy to następstwo pogwałcenia godności pracy ludzkiej"17. Problem ubóstwa musi niepokoić sumienie każdej władzy politycznej, ponieważ wielu ludzi żyje w warunkach, które uwłaczają ich godności. Walka z ubóstwem domaga się obecnie działań kompleksowych, a w dobie globalizacji szczególnie ważne i potrzebne są nowe porozumienia między instytucjami narodowymi i międzynarodowymi a organizacjami obywatelskimi i inicjatywami prywatnymi, aby w ten sposób sprostać próbie zaradzenia ubóstwu dzisiejszego świata i należycie kształtować przyszłość ${ }^{18}$. Ten wielki wysiłek podejmowany na rzecz ludzi ubogich przez różne instytucje narodowe i międzynarodowe spotyka się z ogromną troską Kościoła.

Ważnym zadaniem państwa na dziś jest też prowadzenie polityki ochrony środowiska naturalnego. Według Jana Pawła II kryzys ekologiczny uwydatnia pilną moralną potrzebę nowej solidarności. Państwa powinny być coraz bardziej solidarne i wzajemnie się uzupełniać $\mathrm{w}$ działaniach na rzecz rozwoju środowiska naturalnego ${ }^{19}$. Z kolei zdaniem Benedykta XVI, aby rozwiązać „problem ekologii”, należy zmienić

${ }^{16}$ Por. J. Koperek, A. Koperek, Polityka rynku pracy wobec problemu bezrobocia, w: Caritas in veritate zasadq polityki społecznej, red. T. Adamczyk, J. Mazur, Lublin 2011, s. 211-214.

17 Benedykt XVI, Encyklika "Caritas in veritate”, Tarnów 2009, nr 63 (dalej: CiV).

${ }_{18}$ Por. J. Wiemeyer, Globalizacja gospodarki jako wyzwanie społeczno-etyczne, thum. B. Szlogar, "Communio" 21 (2001), nr 4, s. 72-73.

${ }^{19}$ Por. Jan Paweł II, Pokój z Bogiem Stwórca, pokój z catym stworzeniem. Orędzie na XXIII Światowy Dzień Pokoju (Watykan - 8 grudnia 1989), „L'Osservatore Romano” (wyd. pol.) 10 (1989), nr 12, s. 21. Por. K. Topfer, Ekologia i polityka. Ochrona środowiska jako cel państwa, "Communio” 12 (1992), nr 6, s. 75-81. 
ludzką mentalność, ponieważ prawdziwy rozwój ludzki jest hamowany albo uniemożliwiany przez postawy, w których nie przyjmuje się w pełni zasady miłości i prawdy ${ }^{20}$.

Do istotnych zadań polityki demokratycznej należy również troska o zagwarantowanie każdemu obywatelowi prawa do wolności religijnej. Wolność religijna, jako niezbywalny wymóg godności każdego człowieka, leży u podstaw wszystkich praw ludzkich. Dlatego jest ona niezbędnym czynnikiem dobra osoby i całego społeczeństwa ${ }^{21}$. Prawo człowieka do praktykowania własnej religii jest istotnym warunkiem każdego ustroju demokratycznego. Wszystkie formy gwałcenia wolności religijnej przynoszą szkody każdemu państwu. Rządzący powinni zatem okazywać poszanowanie do przekonań religijnych każdego człowieka oraz uznawać szczególny wkład religii w postęp cywilizacji i rozwój narodów. Przestrzeganie prawa do wolności religijnej jest niejako punktem odniesienia i probierzem innych podstawowych praw.

Wspólnota polityczna istnieje zatem dla dobra wspólnego danej społeczności, z zastrzeżeniem jednak, że należy ją rozumieć w duchu personalistycznym, a nie materialistycznym. Dlatego papież Jan Paweł II stwierdza, że człowiek jest kryterium życia politycznego: „podstawowym kryterium polityki uprawianej na rzecz osoby i społeczeństwa, jest dążenie do wspólnego dobra jako dobra wszystkich ludzi i całego człowieka"22. Personalistyczny wymiar polityki podkreślił papież jeszcze mocniej, gdy stwierdził, że racją bytu wszelkiej polityki jest służba dla człowieka, albowiem wszelka działalność polityczna jest ostatecznie „z człowieka”, „przez człowieka” i „dla człowieka”23. Dlatego należy akcentować potrzebę zaangażowania politycznego każdego człowieka.

${ }^{20}$ Por. CiV 55. Por. także: E. Albińska, Dylematy polityki ochrony środowiska naturalnego, w: Caritas in veritate zasada polityki społecznej..., s. 261-272.

${ }^{21}$ Por. Jan Paweł II, Wolność religijna warunkiem pokojowego wspótżycia. Orędzie na XXI Światowy Dzień Pokoju (Watykan - 8 grudnia 1988), „L'Osservatore Romano” (wyd. pol.) 9 (1988), nr 1, s. 1.

22 Jan Paweł II, Adhortacja apostolska "Christifideles laici”, Poznań 1989, nr 24 (dalej: ChL). Por. M. Zięba, Wspólnota polityczna w świetle Centesimus annus, w: Jan Paweł II, Centesimus annus. Tekst $i$ komentarze..., s. 133-151.

${ }^{23}$ Por. Jan Paweł II, Na forum spokoju i sprawiedliwości. Orędzie do Organizacji Narodów Zjednoczonych (Nowy Jork - 2 październik 1979), w: Dokumenty nauki społecznej Kościoła, cz. 2, red. M. Radwan, L. Dyczewskio, A. Stanowski, Rzym-Lublin 1996, s. 121. 


\section{KONIECZNOŚĆ EDUKACJI I FORMACJI POLITYCZNEJ}

Popierając demokrację jako formę ustroju politycznego państwa, nauka społeczna Kościoła kładzie nacisk na dojrzałe i aktywne uczestnictwo każdego człowieka w działalności politycznej demokratycznego państwa i potrzebę nieustannej edukacji i formacji politycznej.

Papież Jan Paweł II mówi jasno: „prawo i obowiązek uczestniczenia w polityce dotyczy wszystkich i każdego"24. Zaangażowanie polityczne jest więc nie tyle przywilejem, z którego można dowolnie korzystać, co poważnym obowiązkiem, którego celem jest troska o dobro wspólne: osoby i społeczeństwa. Sobór ujął ten obowiązek w kategorię powołania, na które trzeba uczciwie odpowiedzieć: „wszyscy chrześcijanie niech odczuwają swoje szczególne i sobie właściwe powołanie we wspólnocie politycznej, na mocy którego winni świecić przykładem, sumiennie spełniać obowiązki i służyć dobru wspólnemu"25. Sobór zachęca tych, którzy posiadają szczególny talent do działalności politycznej, aby doskonalili się $\mathrm{w}$ tej sztuce i działali roztropnie w duchu miłości i z odwagą polityczną składali świadectwo jedności wiary i życia moralnego ${ }^{26}$.

Katolicka nauka społeczna stwierdza wyraźnie, że cały Kościół, tzn. hierarchia, kapłani, osoby zakonne oraz wszyscy świeccy powinni brać żywy udział $\mathrm{w}$ polityce. $\mathrm{W}$ szczegółowych zaleceniach następuje jednak wyraźne zróżnicowanie oczekiwań skierowanych wobec świeckich i wobec duchownych. Działalność polityczna jest dziedziną zarezerwowaną jedynie dla ludzi świeckich. Natomiast Kościół hierarchiczny nie angażuje się bezpośrednio $\mathrm{w}$ działalność polityczną, nie należy to do jego misji, lecz musi i powinien zająć się polityką rozumianą jako

${ }^{24}$ ChL 42. Por. M. Florczyk, Teologiczne motywy zaangażowania świeckich $w \dot{z} y$ cie polityczne, w: Komisja Duszpasterstwa Episkopatu Polski, Ewangelizacja u progu Trzeciego Tysiaclecia. Program duszpasterski na rok 2000-01, E. Szczotok, A. Liskowackiej, Katowice 2000, s. 369-377; P. Nitecki, Ewangelizacja i polityka, w: Komisja Episkopatu Polski Duszpasterstwa Ogólnego, Ewangelizacja w tajemnicy i misji Kościoła. Program duszpasterski na rok 1994-1995, E. Szczotok, A. Liskowackiej, Katowice 1994, s. $416-428$.

${ }^{25}$ KDK 75.

${ }^{26}$ Por. tamże. Por. także: Benedykt XVI, Polityka a świadectwo o Chrystusie i praktykowanie miłości. Przemówienie do uczestników zgromadzenia plenarnego Papieskiej Rady ds. Świeckich (Watykan - 21 maja 2010), „L'Osservatore Romano” (wyd. pol.) 31 (2010), nr 7, s. 45; K. Ryczan, Zaangażowanie katolików w życie społeczno-polityczne, w: Zaangażowanie chrześcijan w życiu społecznym, red. A. Marcol, Opole 1994, s. 9-33. 
troska o dobro wspólne. Podstawowym zadaniem kapłanów jest służba prawdzie i sprawiedliwości $w$ ramach doczesnej ludzkiej egzystencji, ale zawsze pod kątem zbawienia wiecznego. Kapłani mają być przywódcami duchowymi, którzy starają się ukierunkować i polepszyć serca wiernych, aby się nawrócili i żyli w miłości do Boga i do bliźniego, aby pracowali dla rozwoju człowieka i dla jego większej godności. Natomiast nie mogą być przywódcami politycznymi czy funkcjonariuszami władzy świeckiej. Słuszny jest więc apel Jana Pawła II kierowany do kapłanów: „A kiedy podczas pełnienia waszej posługi napotkacie na problemy dotyczące konkretnej opcji natury politycznej, nie omieszkajcie głosić zasad moralnych leżących u podstaw wszystkich dziedzin ludzkiego działania. Niemniej porządkowanie spraw doczesnych według planu Bożego pozostawiajcie osobom świeckim, które otrzymały właściwą formację sumienia. Wy macie być twórcami braterstwa i wspólnoty, a nigdy podziałów, dokonywanych w imię tych opcji, za którymi wierni mają prawo opowiedzieć się, dając wyraz swoim przekonaniom" ${ }^{27}$.

Tak więc pole działalności politycznej jest domeną zaangażowania ludzi świeckich. „Nowe sytuacje zarówno w Kościele, jak i w życiu społecznym, ekonomicznym, politycznym i kulturalnym domagają się dzisiaj ze szczególną siłą zaangażowania świeckich. Bierność, która zawsze była nie do przyjęcia, dziś bardziej jeszcze staje sie winą. Nikomu nie godzi się trwać w bezczynności"28. Usprawiedliwieniem dla bierności, w dziedzinie życia politycznego, nie mogą być negatywne doświadczenia osób i całych grup społecznych w poszczególnych krajach czy też oskarżenia o karierowiczostwo, kult władzy czy korupcję, a w końcu powodem bierności nie może być przekonanie, że polityka sama w sobie musi być dziedziną moralnie zagrożoną. Nawet jeśli jest prawdą, że w dziedzinie polityki istnieje wiele zła i nieuczciwości, to sytuacja ta nie może prowadzić do podstawy dystansu lub wycofania się w prywatność. Nieobecność katolików świeckich w życiu politycznym sprawia, że $\mathrm{w}$ dziedzinie tej zaczynają się uaktywniać ci, którzy źle rozumieją dobro wspólne albo manipulują nim dla swoich partykularnych celów. Tak więc zło istniejące $\mathrm{w}$ polityce nic może być powodem zgorszenia, ale powinno stanowić wezwanie do uczestniczenia w niej. Świeccy powinni

${ }^{27}$ Jan Paweł II, Spotkanie z duchowieństwem (San Juan, Puerto Rico - 12 października 1984). w: Wyzwania. Wypisy z lektury nauczania społecznego Papieża Jana Pawła II, red. J. Chrapek, J. Żakowski, Kraków-Warszawa 1987, s. 74-75.

${ }^{28}$ Por. ChL 3. 
zatem brać czynny udział $\mathrm{w}$ chrześcijańskich zrzeszeniach, związkach zawodowych, stowarzyszeniach, wyborach, jako reprezentanci parlamentarni, poprzez świeckie, niekoniecznie specyficznie chrześcijańskie ugrupowania ${ }^{29}$.

Świeccy katolicy są bezpośrednio odpowiedzialni za politykę Kościoła, będąc współuczestnikami politycznej regulacji współżycia, poszukiwania kompromisów i równowagi sił w konfliktach, a także orędownikami dobra wspólnego, sprawiedliwości i wewnętrznego pokoju. Katolicy mają być aktywnymi w świecie nie na polecenie Kościoła, ale jako Kościół, zwłaszcza w tych obszarach, gdzie Kościół tylko przez nich może wypełniać swoje posłannictwo. Świeccy nie powinni zatem rezygnować z politycznej działalności, jeśli chcą współtworzyć doczesny porządek w służbie człowieka, przepełniając go duchem służby, uczciwością i prawdomównością, sprawiedliwością w obchodzeniu się z publicznymi środkami, chrześcijańską solidarnością, polityczną kompetencją, zdolnością respektowania praw życia politycznego ${ }^{30}$.

$\mathrm{W}$ tej perspektywie istnieje konieczność formowania człowieka do podjęcia odpowiedzialnej obecności we współczesnym życiu politycznym, zwłaszcza, gdy obecność ta ma być naznaczona wniesieniem $\mathrm{w}$ ten świat wartości chrześcijańskich ${ }^{31}$. Formacja polityczna jest niezwykle ważnym wyznacznikiem świadomości społecznej. Powinna objąć zarówno wykształcenie polityczne, jak i odpowiednie ukształtowanie sumienia i postaw osobowych ${ }^{32}$.

Ważną rolę edukacyjną odgrywa z pewnością sposób sprawowania władzy przez aktualnie dominujące siły polityczne. Praktyka polityczna oparta na zasadach sprawiedliwości społecznej, praworządności, uczciwości jest istotnym składnikiem świadomości i kultury politycznej społeczeństwa. Papież Benedykt XVI stwierdza jasno i dosadnie: „Państwo,

29 Por. W. Kawecki, Dylematy moralne wspótczesnego człowieka, Warszawa 2003, s. 190.

${ }^{30}$ Por. A. Zwoliński, Katolik i polityka, Kraków 1999, s. 54-62. Por. szerzej: M. Vidal, Etica civil y sociedad democratica, Bilbao 2001.

${ }^{31}$ Por. szerzej: A. Derdziuk, Świadectwo wartości w polityce, „Forum Teologiczne" 11 (2010), s. 35-50.

32 Por. J. Wróbel, Prymat racji moralnych w życiu politycznym, "Roczniki Teologiczne" 38-39 (1991-1992), z. 3, s. 25-43; T. Homa, Kulturotwórczy i polityczny wymiar działalności edukacyjnej, „Horyzonty Wychowania” 3 (2004), s. 59-60; J. Salij, Autonomia polityki i prawo moralne, "Znak” 49 (1997), nr 7, s. 65-75; B. Suchodolski, Wychowanie mimo wszystko, Warszawa 1990, s. 85-92. 
które nie kieruje się sprawiedliwością, zredukowałoby się do wielkiej bandy złodziei"33. Z tego wynika, że frustracja i zachowana agresywne obywateli stanowią rezultat postrzegania i oceny błędnych sposobów sprawowania władzy.

Obok sposobu sprawowania władzy, a więc aktualnej praktyki politycznej, ważną rolę $\mathrm{w}$ edukacji życia politycznego odgrywa także wiedza o gospodarce i mechanizmach polityki. Ma ona zasadnicze znaczenie $\mathrm{w}$ procesie powstawania różnorodnych postaw i ocen względem faktów, zjawisk i procesów zachodzących w systemie gospodarczym i politycznym. Niezbędną wiedzę na temat ekonomii i polityki winni przekazywać dzieciom i młodzieży rodzice, szkoły, różnego rodzaju placówki wychowawcze, a także środki społecznej komunikacji ${ }^{34}$. Systemy edukacyjne dostarczają jednak obywatelom nie tylko sumy informacji, lecz także przekazują system wartości, wzorce postępowania. I w tej właśnie sferze edukacji politycznej katolicka nauka społeczna może odegrać bardzo ważną rolę.

Skoro działalność polityczną mają prowadzić ci, którzy są ochrzczeni, czyli obdarzeni nowym życiem w Chrystusie, to ich formacja nie może być ograniczona jedynie do wymiaru przedmiotowego, fachowego, ale musi mieć charakter duchowy. Formowanie w duchu katolickim polega przede wszystkim na kształceniu odpowiedzialności przez głoszenie nauki Ewangelii, wskazywaniu na wspólne dobro społeczności ludzkiej, którego syntezą i fundamentem jest Bóg, oraz na próbie budowania jedności. Wychowanie polityczne powinno polegać także na dawaniu przez katolików dobrego przykładu, budowaniu organizacji i stowarzyszeń, które w praktyce podjęłyby współodpowiedzialność za życie publiczne. Dnia 12 stycznia 1993 r. Jan Paweł II powiedział do biskupów polskich z okazji ich wizyty ad limina Apostolorum, że „niezastąpionym środkiem formacji apostolskiej są organizacje, stowarzyszenia i ruchy katolickie. Wśród nich szczególne miejsce zajmuje Akcja Katolicka"35.

${ }^{33}$ Benedykt XVI, Encyklika "Deus caritas est”, Kraków 2005, nr 28.

${ }^{34}$ Por. E. Aronson, Człowiek - istota społeczna, tłum. J. Radzicki, Warszawa 1987, s. 79-129.

35 Por. Jan Paweł II, Przemówienie Ojca Świętego do Biskupów polskich z okazji wizyty ",ad limina Apostolorum” (Watykan - 12 stycznia 1993), „Niedziela” 4 (1993), nr 4, s. 7. 


\section{ZAKOŃCZENIE}

Z przeprowadzonych analiz wynika, że całą działalność polityczną trzeba pojmować w kategoriach moralnych, ponieważ w jej centrum znajduje się zawsze człowiek i jego działanie, które może być tak dobre, jak i złe. Nie wolno uprawiać polityki według zasad ideologii skuteczności i sukcesu, bez liczenia się z wartościami ogólnoludzkimi i prawami moralnymi. Polityka, jak wiele innych dziedzin ludzkiego życia, potrzebuje pierwiastka duchowego i systemu wartości. Przestrzeganie zasad etycznych w obrębie polityki jest gwarancją właściwego funkcjonowania państwa oraz zabezpieczenia praw jednostki. Do tego potrzeba odpowiedniej formacji, zgodnej z zasadami społecznej nauki Kościoła, aby można było przenikać świat polityki wartościami i duchem chrześcijańskim.

Streszczenie. Przestrzeganie zasad moralnych $\mathbf{w}$ działalności politycznej powinnością sumienia. Życie obywatela to - przynajmniej z chrześcijańskiego punktu widzenia - droga, która prowadzi do Boga, a na której spotkać można co najmniej dwie niewykluczające się rzeczywistości: polityczną i religijną. Chrześcijanin winien się angażować w życie polityczne, a jednocześnie postępować zgodnie z właściwym systemem moralnym. Całą działalność polityczną trzeba pojmować w kategoriach moralnych, ponieważ w jej centrum znajduje się zawsze człowiek i jego działanie, które może być tak dobre, jak i złe. Nie wolno uprawiać polityki według zasad ideologii skuteczności i sukcesu, bez liczenia się z wartościami ogólnoludzkimi i prawami moralnymi. Przestrzeganie zasad etycznych w obrębie polityki jest gwarancją właściwego funkcjonowania państwa oraz zabezpieczenia praw jednostki. Zdając sobie sprawę z możliwych zagrożeń w dziedzinie polityki, trzeba mówić o potrzebie formacji moralnej, dla wszystkich pełniej uczestniczących w życiu politycznym. Formacja ta jest konieczna, aby przenikać świat polityki duchem służby na rzecz dobra wspólnego.

Słowa kluczowe: życie polityczne, moralność, sumienie, dobro wspólne, demokracja, formacja

Abstract. Adherence to moral principles in political activity as a duty of conscience. Life of a citizen is - at least from Christian point of view - a road that leads to God and on which at least two not excluding realities can be met: political and religious. The Christian should engage in the political life and at the same time follow the appropriate moral system. The entire political activity must be understood in moral terms because it is centered on human life and actions which might be good as well as bad. The politics cannot be practiced according to the rules of ideology of effectiveness and success, without taking universal values and moral laws into account. Following ethical principles within the policy guarantees 
the proper functioning of the state and the protection of individual rights. Realizing the potential risks in the field of politics, we have to talk about the need for moral formation for all fully participating in political life. This formation is necessary to infiltrate the world of politics with the spirit of service to the common good.

Keywords: political life, morality, conscience, the common good, democracy, formation. 